words themselves. Nash perceived in 1930 and reiterates in his book that "feeding grounds" are not areas in which tsetses habitually feed, but open spaces in which those flies that, by accident, have failed to encounter a normal host, aceumulateand, in a starved condition, attack animals that may be ignored in the woodland, the "true habitat".

Nash also pioneered research on resting behaviour. His studies soon found a use in the application of residual insecticides. Possibly, however, his greatest contribution to the solution of the trypanosomiasis problem was his description of types of man-fly contact, especially of Glossina palpalis, and of their significance in epidemies of sleeping sickness. The account of the women at the Sambo waterhole at the height of the Nigerian epidemic in 1935 is a classical example of a natural focus of infection. Detailed studies of the environments in which such foci were formed were followed by application of knowledge so gained to the planning of control. One regret is that Nash has not reproduced in this book the splendid description of an old Nigerian walled town that appeared in his 1948 report on the Anchau Settlement Scheme.

Nash now directs the Tsetse Research Laboratory at Bristol, where he has been outstandingly successful in rearing colonies of Glossina. As a result of this work (and parallel success in Lisbon and, later, in Paris) tsetses are acquiring new roles as laboratory animals in universities in temperate regions. A generation of research workers is growing up, many of whom have never seen these insects in the wild. To these specialists, at any rate, Nash's well illustrated book, with its anecdotes of life in the fly belts, will give entertainment and also enlighten. ment.

J. FORD

\section{FISH FOR FOOD}

\section{Theory of Fish Population Dynamics as the Biological Background for Rational Exploitation of Fishery Resources}

By George V. Nikolskii. Translated by J. E. S. Bradley. Edited by R. Jones. Pp. xvi +323 . (Oliver and Boyd: Edinburgh, November 1969.) $170 s$.

THe world catch of fish has risen at about 8 per cent per annum during the past ten years. The FAO estimate of the 1968 total was 64 million metric tons, and FAO statistics also indicate a slight increase in world food production. The world population is, however, increasing at a greater rate than the food production. A continuing increase in fish landings is therefore obviously of great importance to man, but there is a limit to the amount that can be taken each year from each fish stock. In a recent article S. J. Holt outlined three factors which will influence fish catches: first, the exploitation of new stocks; second, the possibility of incrcased cropping of existing populations; and third, the successful management of our fisheries to ensure maximum sustainable yiolds.

Nikolskii's book should be read against this general context of the world food problem and, in particular, the contribution that fisheries can make to tho situation. If they aro to offer advice on the management and improvement of world fisheries, fishery biologists must understand tho interaction of individual fish, populations of fish and the abiotic factors infuencing the fish; thoy must understand the influence of these factors on the internal environment of fish. This is a vast subject and there are few people who have the comprehensive knowledge to attempt a book on it: Nikolskii is one of these people.

His approach to these factors is extremely stimulating. The two references in the forcword will pcrhaps illuminate this: Sechenov's views on the unity of the organism and the environment, and Krylov's comment that "mathematics resembles a mill grinding what is put under it".

The book surveys the whole field of fish population dynamics, starting with the history of the subject and ending with a review of future problems. The author demonstrates his wide knowledge of the subject and, within the limitations of the size of the book in relation to the magnitude of the subject, there is an impressive coverage of detail, including a substantial number of non-Russian references. This is a very readable book which, bccause of the attempt to integrate the numerous factors, both biotic and abiotic, which affect the individual members of a population and hence the whole population from egg to death, should interest a wide field of fishery biologists.

My only major criticism of the book is that occasionally it is teleological; for example, "Growth is directed to regulating numbers or mass of population and also the reproductive rate in relation to the food supply"; or again, "There are many different mechanisms whereby fish adjust their age composition, the main ones being as follows". One must, however, be wary of this type of criticism of a book which has been translated into English from a language such as Russian.

In conclusion, I again express my enthusiasm for the aim of this book and the approach to the subject. Thanks are due to the translators and editor for enabling people like myself, who do not read Russian, to be able to appreciate this book.

D. R. SwIFT

\section{PICTURE GUIDE TO REPRODUCTION}

\section{Sex and Fertility}

By C. Wood. (The World of Science Library.) Pp. 216. (Thames and Hudson: London, January 1970.) $42 s$ boards; $21 \mathrm{~s}$ paper.

Triere has been no shortage in recent years of books and pamphlets on reproductive physiology, conception and contraception. This book is yet another simple guide to add to others previously distributed by various authors or magazines. It is very similar indeed to the recent number on birth control issued by Time Life magazine, even to the content of the many illustrations.

The book is obviously intended to appeal to a wide and, presumably, uncritical audience. The author is primarily concerned with attempts at controlling the population explosion and devotes much of the limited space in the book to this topic. There are chapters describing spermatozoa, ovulation, endocrinology, and contraceptive methods. In spite of the limited amount of text, a chapter on pregnancy is included which hardly bears on the main theme. Final chapters on reproduction in the future and on human improvement cover a hotch-potch of ideas.

The range of topies covered is far too wide. We are jolted through intimate details of fertilization, factory farming, AID, and the like, many of these ideas being given as lengthy but incomplete "asides" beneath the lavish illustrations. In spite of the author's concern with the population explosion, abortion is not even mentioned. The social consequences of expanding populations aro dismissed in nine paragraphs. All the triteness associated with debates on genetic improvement in man is included, yct current embryological techniques for choosing the sex of offspring and for producing chimaeras are not touched upon in spite of the advanced application of these techniques in mammals and their potential ncarapplication to the human situation. An urge to write does not compensate for such an uneritical collcction of material.

Porusal of the text left mo in doubt whether this publication was intended as a book or an illustrated magazine. Why were so many illustrations included, many of them seeming to be purely space fillers and some of doubtful integrity? A whole-page picture, which is described as illustrating an African mother with malnutrition, turns out to be of Biafrans. Apart from the ethies of including such a picture in a section on the consequences of the population explosion, such material is hardly con- 